\title{
Pharmacological Evaluation of Antipyretic and Antioxidant Activities of 80\% Methanol Root Extract and Derived Solvent Fraction of Echinops kebericho M. (Asteraceae) in Mice Model
}

\author{
Tesfaye Yimer $\mathbb{D}^{1},{ }^{1}$ Yohannes Kelifa Emiru, ${ }^{2}$ Zemene Demelash Kifle $\mathbb{D}^{\mathbb{D}},{ }^{3}$ Amien Ewunetei $\mathbb{D}^{\mathrm{D}},{ }^{1}$ \\ Meaza Adugna, ${ }^{3}$ and Eshetie Melese Birru ${ }^{3}$ \\ ${ }^{1}$ Department of Pharmacy, College of Health Science, Debre Tabor University, Debre Tabor, Ethiopia \\ ${ }^{2}$ Department of Pharmacognosy, School of Pharmacy, College of Medicine and Health Sciences, University of Gondar, \\ Gondar, Ethiopia \\ ${ }^{3}$ Department of Pharmacology, School of Pharmacy, College of Medicine and Health Sciences, University of Gondar, Gondar, Ethiopia
}

Correspondence should be addressed to Tesfaye Yimer; yimertesfaye00@gmail.com

Received 9 November 2020; Revised 11 February 2021; Accepted 27 February 2021; Published 16 March 2021

Academic Editor: Ali Imran

Copyright (C) 2021 Tesfaye Yimer et al. This is an open access article distributed under the Creative Commons Attribution License, which permits unrestricted use, distribution, and reproduction in any medium, provided the original work is properly cited.

\begin{abstract}
Background. Toxicity and untoward effects are very ostensible in most standard drugs including antipyretic agents. Searching for conceivable antipyretic drugs with minimal toxicities and side effects from traditional plants is a growing concern to date. Echinops kebericho M. (Asteraceae) is one of the most prominent traditional medicinal plants, which is frequently testified for its traditionally claimed uses of treating fever and different infectious and noninfectious disorders by traditional healers in Ethiopian folk medicine. However, this plant has not been scientifically assessed for its traditionally claimed uses. This study therefore is aimed at investigating the antipyretic and antioxidant activities of $80 \%$ methanol root extract and the derived solvent fraction of Echinops kebericho M. in mouse models. Methods. Successive solvent maceration with increased polarity was used as the method of extractions, and chloroform, ethyl acetate, methanol, and water were used as solvents. After extraction, the crude extract and its derived solvent fractions were assessed for their antipyretic activities using yeast-induced pyrexia while, the antioxidant activities were measured in vitro using the diphenyl-2-picrylhydrazyl (DPPH) assay method. Both the extract and solvent fractions were evaluated at the doses of 100,200 , and $400 \mathrm{mg} / \mathrm{kg}$ for its antipyretic activities, and the antioxidant activity was evaluated at the doses of $50,100,200,400,600,800$, and $1000 \mathrm{mg} / \mathrm{kg}$. The positive control group was treated with standard drug (ASA $100 \mathrm{mg} / \mathrm{kg}$ ), while normal saline-receiving groups were assigned as negative control. Result. E. kebericho crude extract along with its derived solvent fractions showed statistically significant $(p<0.05,0.01$, and 0.001$)$ temperature reduction activities. The maximum percentage of temperature reduction was observed by the highest dose $(400 \mathrm{mg} / \mathrm{kg}) \mathrm{of}$ the crude extract. The aqueous fraction also showed significantly $(p<0.05$ and 0.01$)$ higher temperature reduction than those of ethyl acetate and chloroform fractions. The free radical scavenging activities of the crude extract were also significantly high at the maximum dose, and the aqueous fraction showed the significantly highest antioxidant activity. Conclusion. In general, the data obtained from the present study clarified that the extract possessed significant antipyretic and antioxidant activities, upholding the traditionally claimed use of the plant.
\end{abstract}

\section{Introduction}

Fever is a common medical sign once the human's body temperature goes above the normal range $\left(36.5-37.5^{\circ} \mathrm{C}\right)$ secondary to infection, tissue damage, inflammation, malignancy, graft rejection, and other inflammatory disease conditions [ 1 ,
2]. It is the body's natural defense to create an environment where an infectious agent or damaged tissue cannot survive since many of the microbial agents that cause infection grow supreme at normal body temperatures and their growth is inhibited by temperatures in the fever range [2]. Thus, a lack of fever may contribute to lower resistance to infection, 
delayed recovery, and suboptimal outcome. Lower febrile responses to infection are associated with a higher mortality rate and poor prognosis of any human disorders [3].

Handling of human illnesses with traditional medicinal plants has been an integral part of traditional medicine for centuries nationwide. Significantly, herbal medicines play a valuable role in developed, as well as developing, countries in improving primary healthcare for the reason that they have effective biological and medicinal properties with easy accessibility and low costs [4]. Ethiopia is endowed with leftovers of traditional medicinal plants with wide diversity of active secondary phytoconstituents that are used for treating a variety of human ailments including fever, inflammation, and oxidative stress [5, 6]. Echinops kebericho $\mathrm{M}$. is among the widely used traditional medicinal plants in Ethiopian folk medicine which is frequently testified for its potential on scavenging free radicals and antipyretic potentials by traditional medicine practitioners in different parts of Ethiopia [7].

Conventionally, E. kebericho has been used for the relief of various infectious and noninfectious diseases including fever, headache, cough, diarrhea, malaria, stomach ache, and typhus and also used as taenicides by traditional healers in numerous preparations [8]. For instance, the infusion and inhalation (after burning) of the root is used to heal cough and head ache, respectively, whereas inhalation of the leaf and steam after burning is used to be relieved from inflammation which is habitually known as "mich" by old-style therapists [9]. It is also stated that the Echinops species is used by traditional healers for the treatment of a variety of medical conditions in different preparations. The dried and/or fresh root is fumigated for the prevention of devil sickness, and also, the dried and/or fresh root is crushed and mixed with water, and then after, a cup of the mixture is taken orally to treat head ache. Moreover, fumigation of dried and/or fresh root is used for treating malaria [10]. The dried root of $E$. kebericho is also mixed with coffee and taken orally to be relieved from toothache, head ache, and vomiting, by a traditional healer [11].

Traditional healers also use E. kebericho, by inhaling the dried root to heal inflammation and the evil eye [12]. Inhalation, infusion and smoking of the bulbs of E. kebericho are reported to be used for treating cough and head ache conventionally [13].

Despite of the frequently conveyed evidences about the traditionally claimed uses of E. kebericho by traditional healers, not any scientific reports regarding its antipyretic and antioxidant activities have been found in literatures so far. So, it deemed judicious to investigate the antioxidant and antipyretic activities of the plant scientifically upholding its traditionally claimed uses. The present study is aimed at investigating the antipyretic and antioxidant activities of $80 \%$ methanol root extract and derived solvent fraction of E. kebericho M. in mouse models.

\section{Materials and Methods}

2.1. Materials and Instruments. A rotary evaporator (Yamato, Japan), lyophilizer (Operon, OPR-FDU-5012, Korea), electronic balance (KERN-ALJ 220-4, Germany), tissue drying oven (MEDITE Medizintechnik, Germany), syringes with needles, and feeding tube were used with their respective function.

2.2. Drugs and Chemicals. Normal saline (H. R., Leuven, Belgium), distilled water (Ethiopian Pharmaceutical Manufacturing Factory, Ethiopia), absolute methanol (Indenta Chemicals, India), brewer's yeast (Titan Biotech Ltd., India), and aspirin, obtained from the respective vendors, were used in the experiment.

2.3. Collection, Identification, and Preparation of Plant Materials. The roots of E. kebericho were collected from around Debre Tabor town in South Gondar Zone of the Amhara regional state which is located in the northwest direction and $667 \mathrm{~km}$ away from the capital city Addis Ababa. The plant was then authenticated by botanists in the Department of Biology, College of Natural and Computational Sciences, University of Gondar, where a specimen with voucher number 002TYT/2019 was deposited for further reference.

2.4. Preparation of the Extract. After collecting the experimental plant from its indigenous place, the roots were separated and washed with tap water to remove dusts and any other debris present on it. The roots were then air dried under a shaded area at room temperature and pulverized using a mortar and pestle to get a coarse powder. A total of $3.50 \mathrm{~kg}$ powdered root was macerated using $80 \%$ methanol. The contents were shaken manually each day and allowed to remain within the solvent for 3 days. After 3 days, the extract was filtered first using gauze and then by a Whatman filter paper (no. 1). The marc was remacerated twice using the same volume of solvent to exhaustively extract the plant material. After extraction was completed, the solvent was evaporated under a vacuum using a rotary vapor and oven at $40^{\circ} \mathrm{C}$. The resulting solution was then placed in a deep freezer operating at $-20^{\circ} \mathrm{C}$ till it forms solid ice, and then, the remaining solvent (water) was removed using a lyophilizer. After everything, a brownish gummy residue of the crude extract weighing $224 \mathrm{mg}$ was obtained, giving rise to a percentage yield of $14.93 \%$. Then, the resulting crude extract was kept a within deep refrigerator $\left(-20^{\circ} \mathrm{C}\right)$ till the commencement of the next procedure.

2.5. Preparation of the Solvent Fraction. The dried crude extract was further fractionated using sequential solvent partitioning by different solvents of increasing polarity (chloroform, ethyl acetate, and distilled water) to get different solvent fractions. Eighty grams of the extract was suspended in $400 \mathrm{ml}$ of distilled water in a separatory funnel. The aqueous portion was partitioned three times with $400 \mathrm{ml}$ of chloroform to obtain chloroform fraction. Then, aqueous residue was further fractionated three times with $400 \mathrm{ml}$ of ethyl acetate to obtain the ethyl acetate fraction. Finally, the aqueous solution was collected as the third fraction. The chloroform and ethyl acetate fractions were concentrated in a hot air oven under $40^{\circ} \mathrm{C}$. The aqueous fraction was frozen in a refrigerator overnight and then dried using a lyophilizer. The $\%$ yield of the dried fractions was calculated and the 
fractions obtained were put in airtight bottles and stored in a refrigerator at $-4^{\circ} \mathrm{C}$ until being used.

2.6. Experimental Animals. Healthy adult Swiss albino mice of either sex (25-35 $\mathrm{g}$ and 6-8 weeks of age) were purchased from the Ethiopian Health and Nutrition Research Institute (EHNRI). All mice were fed with commercial pellets and have had access to water ad libitum. The mice were acclimatized for a week before commencement of the experiment in all procedures to minimize stress. All mice used in this study were handled in accordance with the internationally accepted standard guidelines for use of laboratory animals [14].

2.7. Animal Grouping and Dosing. Swiss albino mice of either sex (25-35 g) were randomly divided into twelve groups of six mice each. Group I was assigned as negative control and received vehicles. Group II was served as positive control and treated with standard drugs. Groups III-XII were used as test groups and given the extract of 100, 200, and $400 \mathrm{mg} / \mathrm{kg}$ and aqueous, ethyl acetate, and chloroform fractions of similar doses with the crude, respectively. Doses were selected based on the acute toxicity study done previously [7, 15]. All treatment administrations were performed orally and the maximum volume administered was $0.015 \mathrm{ml} / \mathrm{kg}$.

\section{Evaluation of Antipyretic Activity}

3.1. Brewer's Yeast-Induced Pyrexia. Yeast-induced fever (pathogenic fever) which is the most common model for investigating the antipyretic potentials of natural products and synthetic substances was used to detect the antipyretic potential of $E K$ extract $[16,17]$. Swiss albino mice of either sex were divided into twelve groups $(n=6)$ and fasted over night with free water access. The initial basal rectal temperature of each mouse was measured using a digital thermometer by inserting a thermistor probe about $3 \mathrm{~cm}$ into the rectum. Fever (pyrexia) was induced in all mice by injecting $30 \% \mathrm{w} / \mathrm{v}$ yeast extract powder suspension in $0.9 \%$ normal saline $(10 \mathrm{ml} / \mathrm{kg}(3 \mathrm{~g} / \mathrm{kg}))$ below the nape of the neck subcutaneously. The rectal temperature of each mouse was again recorded after $18 \mathrm{hrs}$ of yeast administration to attune with the stable or plateau phase of fever, i.e., an appropriate time to test antipyretic activity of $E K$ extract. Only mice showing an increase in temperature of at least $0.5^{\circ} \mathrm{C}$ after yeast injection were used for the experiment. After everything, each group of the mice was treated with standard drug: group I (100 mg/kg ASA), vehicle group II (10 ml/kg normal saline), and different doses of the extract, i.e., group III (100 mg/kg), group IV (200 mg/kg), and group V (400 mg/kg). All administrations were performed orally using oral gavage. Finally, the temperature of each mouse was measured at $0.5,1,1.5$, $2,2.5$, and 3 hours after dosing. Percentage reduction in rectal temperature was calculated considering the total fall in temperature to the normal level as described in the following $[18,19]$ :

$$
\text { \%inhibition }=\frac{\text { yeast-induced pyrexia }- \text { posttreatment } T}{\text { yeast-induced pyrexia }} * 100 \text {. }
$$

3.2. Evaluation of Antioxidant Activity. Several concentrations ranging from 50 to $1000 \mu \mathrm{g} / \mathrm{ml}$ of the crude and solvent fractions of E. kebericho were tested for antioxidant activity in the DPPH model. Ascorbic acid was used as the standard drug for the determination of the antioxidant activity by the DPPH method [20, 21].

3.3. Statistical Analysis. Analysis of results was done using Statistical Package for Social Sciences (SPSS) software version 21. All results obtained were expressed as mean \pm standard error of mean (SEM) of responses. The statistical significance was determined using one-way analysis of variance (ANOVA) followed by the Tukey post hoc test to compare variations among groups, and the results were considered significant at $p<0.05$. The analyzed data were then presented using tables and graphs where necessary.

\section{Results}

\subsection{Antipyretic Activity}

4.1.1. Brewer's Yeast-Induced Pyrexia in Mice. The mean temperature reductions produced by all test doses of the crude methanolic extract, aqueous, ethyl acetate, and chloroform fractions of E. kebericho were significant as compared to that of the negative control (Table 1). The percentage temperature reductions of the crude methanolic extract of $E K$ at all test doses employed (100, 200, and $400 \mathrm{mg} / \mathrm{kg}$ ) and ASA $(100 \mathrm{mg} / \mathrm{k})$ were $4.12 \%, 6.5 \%, 6.95 \%$, and $7.5 \%$, respectively, as compared to vehicle-receiving group (Table 2 ). The mean $T$ reduction potential of the crude extract was found to increase in a dose-dependent manner. The fever reduction effect was statistically significant in 200 and $400 \mathrm{mg} / \mathrm{kg}$ $(p<0.01$ and $p<0.001)$ doses of the crude extract starting at $1 \mathrm{hr}$ after administration, and the effect persisted till the $3^{\text {rd }}$ time of observation $(p<0.001)$, while the effect of the lower dose of the crude extract $(100 \mathrm{mg} / \mathrm{kg})$ was observed to be significant $(p<0.05)$ from $1.5 \mathrm{hr}$ after administration onwards $(p<0.01)$. The antipyretic effect of the crude extract at its maximum dose level $(400 \mathrm{mg} / \mathrm{kg}$ ) was commensurable to that of the reference drug (ASA $150 \mathrm{mg} / \mathrm{kg}$ ) (Table 1).

The maximum antipyretic effect of $\mathrm{AF}$ ( $\% T$ reduction) at its test doses employed (100, 200, and $400 \mathrm{mg} / \mathrm{kg}$ ) was observed at the $3^{\text {rd }}$ time of observation with the respective percentage values of $3.9 \%, 5.1 \%$, and $6.9 \%$ (Table 2). This percentage of $T$ reduction effect was found to be increasing in a dose-dependent manner. Temperature reduction effects of the middle and high doses of AF fraction of EK (200 and $400 \mathrm{mg} / \mathrm{kg})$ were statistically significant $(p<0.01$ and $p<$ $0.001)$ starting from $1 \mathrm{hr}$ of administration, while the effect of the lower dose $(100 \mathrm{mg} / \mathrm{kg})$ was statistically significant $(p<0.05)$ from $1.5 \mathrm{hrs}$ of administration onwards (Table 1$)$.

On the other hand, the antipyretic effects of EAF of EK at its test doses $(100,200$, and $400 \mathrm{mg})$ were statistically significant starting from the $1^{\text {st }}$ observation $(p<0.05$ and $p<0.01)$ and $T$ reduction activities of all doses persisted till the last observation. Each EAF of EK (100, 200, and $400 \mathrm{mg} / \mathrm{kg})$ produced antipyretic percentages of $0.92 \%, 2.45 \%$, and $2.54 \%$, respectively, at the $3^{\text {rd }}$ time of observation. 


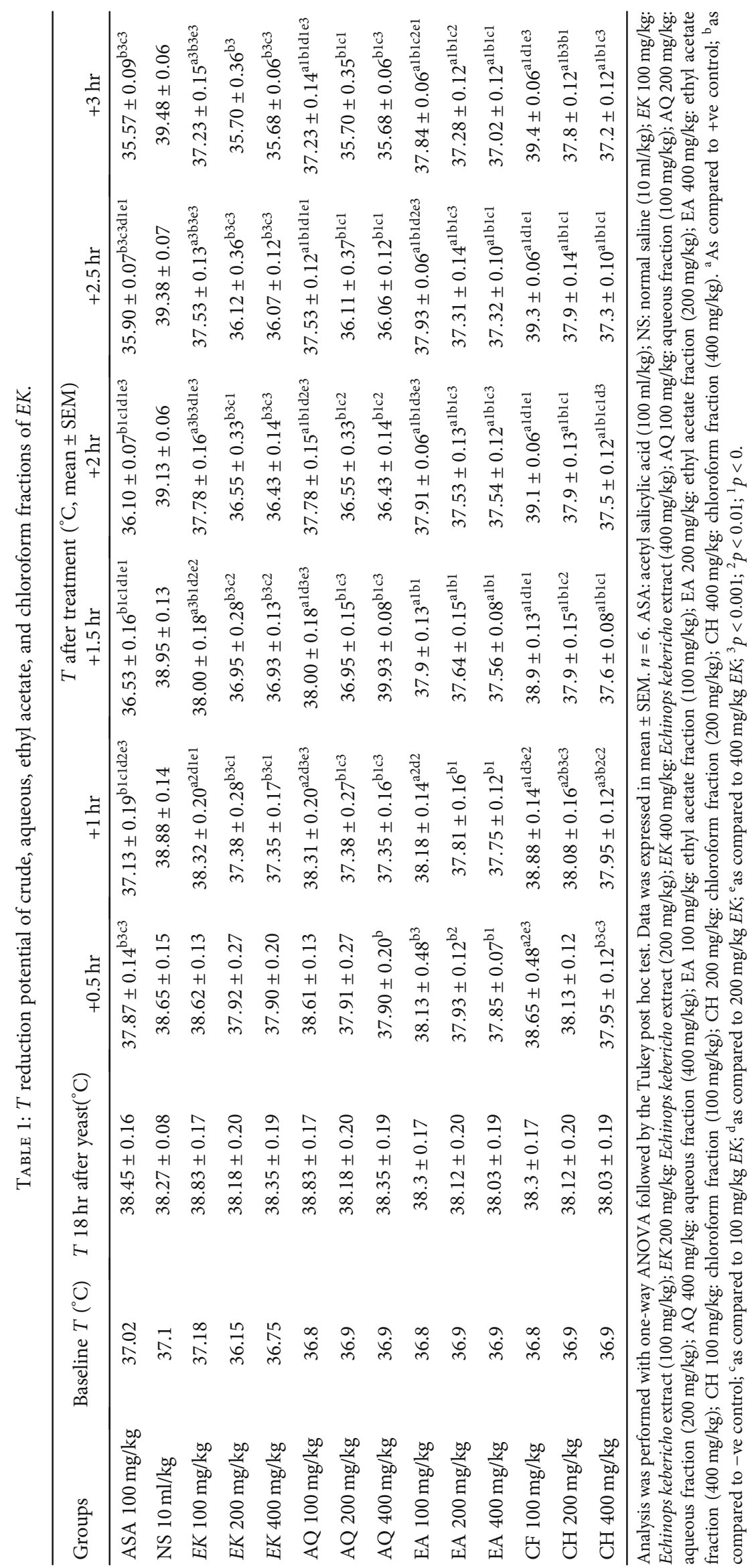


TABLE 2: Percent temperature reduction potentials of crude extract, aqueous, ethyl acetate, and chloroform fractions of E. kebericho.

\begin{tabular}{lcccccc}
\hline Groups & $+0.5 \mathrm{hr}$ & $+1 \mathrm{hr}$ & $+1.5 \mathrm{hr}$ & $+2 \mathrm{hr}$ & $+2.5 \mathrm{hr}$ & $+3 \mathrm{hr}$ \\
\hline ASA $150 \mathrm{mg} / \mathrm{kg}$ & 1.51 & 3.42 & 4.98 & 6.11 & 6.63 & 7.49 \\
EK $100 \mathrm{mg} / \mathrm{kg}$ & 0.56 & 1.33 & 2.14 & 2.70 & 3.34 & 4.12 \\
EK $200 \mathrm{mg} / \mathrm{kg}$ & 0.70 & 2.10 & 3.23 & 4.27 & 5.41 & 6.50 \\
EK $400 \mathrm{mg} / \mathrm{kg}$ & 1.17 & 2.61 & 3.69 & 4.10 & 5.95 & 6.95 \\
AQ $100 \mathrm{mg} / \mathrm{kg}$ & 0.35 & 1.04 & 1.86 & 2.34 & 3.20 & 3.90 \\
AQ $200 \mathrm{mg} / \mathrm{kg}$ & 0.61 & 1.92 & 3.19 & 4.11 & 5.07 & 6.38 \\
AQ $400 \mathrm{mg} / \mathrm{kg}$ & 1.17 & 2.56 & 3.69 & 5.08 & 5.95 & 6.91 \\
EA $100 \mathrm{mg} / \mathrm{kg}$ & 0.13 & 0.22 & 0.61 & 0.65 & 0.61 & 0.92 \\
EA $200 \mathrm{mg} / \mathrm{kg}$ & 0.52 & 0.31 & 1.31 & 1.70 & 2.05 & 2.45 \\
EA $400 \mathrm{mg} / \mathrm{kg}$ & 0.66 & 0.88 & 1.23 & 1.53 & 2.02 & 2.54 \\
CH $100 \mathrm{mg} / \mathrm{kg}$ & 0.09 & 0.22 & 0.61 & 0.65 & 0.61 & 0.92 \\
CH $200 \mathrm{mg} / \mathrm{kg}$ & 0.52 & 0.83 & 1.31 & 1.70 & 2.05 & 2.44 \\
CH $400 \mathrm{mg} / \mathrm{kg}$ & 0.66 & 0.87 & 1.22 & 1.53 & 2.02 & 2.54 \\
\hline
\end{tabular}

Data was expressed as mean \pm SEM. $n=6$; ASA: acetyl salicylic acid $(100 \mathrm{mg} / \mathrm{kg}) ; \mathrm{NS}$ : normal saline $(10 \mathrm{ml} / \mathrm{kg}) ;$ EK $100 \mathrm{mg} / \mathrm{kg}$ : Echinops kebericho extract $(100 \mathrm{mg} / \mathrm{kg}) ;$ EK $200 \mathrm{mg} / \mathrm{kg}$ : Echinops kebericho extract (200 mg/kg); EK $400 \mathrm{mg} / \mathrm{kg}$ : Echinops kebericho extract ( $400 \mathrm{mg} / \mathrm{kg}$ ); AQ $100 \mathrm{mg} / \mathrm{kg}$ : aqueous fraction $(100 \mathrm{mg} / \mathrm{kg}) ;$ AQ $200 \mathrm{mg} / \mathrm{kg}$ : aqueous fraction (200 mg/kg); AQ $400 \mathrm{mg} / \mathrm{kg}$ : aqueous fraction $(400 \mathrm{mg} / \mathrm{kg})$; EA $100 \mathrm{mg} / \mathrm{kg}$ : ethyl acetate fraction $(100 \mathrm{mg} / \mathrm{kg}) ; \mathrm{EA} 200 \mathrm{mg} / \mathrm{kg}$ : ethyl acetate fraction $(200 \mathrm{mg} / \mathrm{kg}) ;$ EA $400 \mathrm{mg} / \mathrm{kg}$ : ethyl acetate fraction $(400 \mathrm{mg} / \mathrm{kg}) ; \mathrm{CH}$ $100 \mathrm{mg} / \mathrm{kg}$ : chloroform fraction ( $100 \mathrm{mg} / \mathrm{kg}$ ); $\mathrm{CH} 200 \mathrm{mg} / \mathrm{kg}$ : chloroform fraction $(200 \mathrm{mg} / \mathrm{kg})$; $\mathrm{CH} 400 \mathrm{mg} / \mathrm{kg}$ : chloroform fraction $(400 \mathrm{mg} / \mathrm{kg})$. $T$ : temperature.

Like the ethyl acetate fraction, the chloroform fraction at its test doses $(100,200$, and $400 \mathrm{mg} / \mathrm{kg}$ ) started reducing yeast-induced pyrexia starting from the $1^{\text {st }}$ observation onwards. The antipyretic effect of the maximum dose of the ethyl acetate fraction $(400 \mathrm{mg} / \mathrm{kg})$ was significant $(p<0.05)$ starting from $1.5 \mathrm{hrs}$ of observation, and the effect continued till the $3^{\text {rd }}$ time of observation $(p<0.01)$ (Table 1$)$.

4.1.2. Antioxidant Activity. Several concentrations ranging from 50 to $1000 \mu \mathrm{g} / \mathrm{ml}$ of the crude and solvent fractions of $E K$ were tested for antioxidant activity in the DPPH model. The aqueous fraction exhibited a maximum antioxidant activity (92.19\%) with an $\mathrm{IC}_{50}$ value of $4.11 \mu \mathrm{g} / \mathrm{ml}$ (Table 3 ). There was a dose-dependent increase in the percentage antioxidant activity for all concentrations tested. Ascorbic acid was used as the standard drug for the determination of the antioxidant activity by the DPPH method. Ascorbic acid at a concentration of $1000 \mu \mathrm{g} / \mathrm{ml}$ exhibited a percentage inhibition of $96.49 \%$ and with an $\mathrm{IC}_{50}$ value of $2.76 \mu \mathrm{g} / \mathrm{ml}$ (Figure 1). The $\mathrm{IC}_{50}$ value was observed to be $5.89 \mu \mathrm{g} / \mathrm{ml}$ for the crude extract, $9.58 \mu \mathrm{g} / \mathrm{ml}$ for the ethyl acetate fraction, and $15.00 \mu \mathrm{g} / \mathrm{ml}$ for the chloroform fraction (Figure 1).

\section{Discussion}

In this study, the potential antipyretic and antioxidant effects of hydromethanol crude extract and solvent fractions of $E K$ were investigated using different animal models. In brewer's yeast-induced pyrexia, the crude extract, aqueous, and ethyl acetate fractions showed significant $(p<0.01$ and $p<0.001)$ temperature reduction potential than the chloroform fraction. In addition, the aqueous fraction exhibited a maximum antioxidant activity in the DPPH model than those in crude extract, ethyl acetate, and chloroform fractions.

In the evaluation of antipyretic activities of hydromethanol root extract of $E K$ and its solvent fraction, yeast-induced pyrexia, also called pathogenic fever, was employed. Induction of $30 \% \mathrm{w} / \mathrm{v}$ freshly prepared yeast in $0.9 \%$ normal saline subcutaneously below the nape of the neck of the mouse-induced fever $(0.01 \mathrm{mg} / \mathrm{g})$ after $18 \mathrm{hrs}$ of induction [19]. The presence of proteins in yeast is linked to fever via a variety of inflammatory reactions in this method. The production of proinflammatory cytokines such as IL- $1 \beta$ and IL-6, IFN- $\alpha$ and TNF- $\alpha$, and PGs like $\mathrm{PGE}_{2}$ and $\mathrm{PGI}_{2}$ is responsible for elevating the body temperature by acting on the brain which sets the thermoregulatory center at a lower-temperature regulatory area of the hypothalamus [22].

In the present study, $80 \%$ methanolic root extract of $E K$ at the three test doses employed (100, 200, and $400 \mathrm{mg} / \mathrm{kg}$ ) demonstrated a significant fever reduction effect $(p<0.05, p<0.01$, and $p<0.001$, respectively) after $1 \mathrm{hr}$ of administration and the effects persisted significantly at the $3^{\text {rd }}$ time of observation in all test doses $(p<0.05$, $p<0.01$, and $p<0.001$, respectively) as compared with the negative control. The maximum fever reduction effect in all test doses of the extract $(100,200$, and $400 \mathrm{mg} / \mathrm{kg})$ was observed at the $3^{\text {rd }}$ time of observation with the respective percentage values of $4.12 \%, 6.50 \%$, and $6.95 \%$ (Table 2). All the values gained were as per mean temperature change from the pre-extract/drug/vehicle value over each $\mathrm{hr}$ period and predrug yeast-induced temperature recorded for the same mice. The effects of temperature reduction potentials of the extract were found to be significant in a dose-dependent manner, i.e., the lower dose of the extract $(100 \mathrm{mg} / \mathrm{kg})$ showed significantly lower effect than the middle dose $(200 \mathrm{mg} / \mathrm{kg})(p<0.01)$ and high dose $(400 \mathrm{mg} / \mathrm{kg}) \quad(p<0.001)$ while the middle dose showed significantly lower antipyretic activity $(p<0.05)$ than the higher dose and the higher dose of the extract showed comparable temperature reduction potential with the standard drug ( $p>0.05$ ) (ASA $100 \mathrm{mg} / \mathrm{kg}$ ) from the $1^{\text {st }} \mathrm{hr}$ of observation and the effect continued throughout the observation times with the respective values of $6.95 \%$ and $7.50 \%$ (Figure 1).

The aqueous fraction (AF), at its lower and middle doses employed $(100 \mathrm{mg} / \mathrm{kg}$ and $200 \mathrm{mg} / \mathrm{kg})$, showed statistically significant $T$ reduction effect in a dose-dependent manner starting from the $1^{\text {st }}$ hour of observation onwards while the maximum dose $(400 \mathrm{mg} / \mathrm{kg})$ showed statistically significant antipyretic effect starting from $0.5 \mathrm{hrs}$ of observation onwards (Table 1). The aqueous fraction showed the highest antipyretic effect, suggesting that the active phytoconstituents of the extract responsible for temperature reduction might be majorly polar and dissolved with more polar solvents like distilled water.

On the other hand, EAF showed significantly lower the antipyretic activity than the aqueous fraction $(p<0.05)$ 
TABLE 3: Antioxidant activities and $\mathrm{IC}_{50}$ values of the crude and solvent fractions of Echinops kebericho.

\begin{tabular}{lcccccccc}
\hline Extract & $50 \mu \mathrm{g} / \mathrm{ml}$ & $100 \mu \mathrm{g} / \mathrm{ml}$ & $200 \mu \mathrm{g} / \mathrm{ml}$ & $400 \mu \mathrm{g} / \mathrm{ml}$ & $600 \mu \mathrm{g} / \mathrm{ml}$ & $800 \mu \mathrm{g} / \mathrm{ml}$ & $1000 \mu \mathrm{g} / \mathrm{ml}$ & $\mathrm{IC} 50(\mu \mathrm{g} / \mathrm{ml})$ \\
\hline Crude & $13.23 \pm 2.01$ & $31.56 \pm 2.14$ & $68.72 \pm 1.37$ & $79.83 \pm 1.57$ & $86.43 \pm 0.87$ & $88.82 \pm 1.49$ & $89.32 \pm 0.96$ & $5.89 \pm 1.02$ \\
EA & $11.57 \pm 1.89$ & $26.81 \pm 3.07$ & $51.32 \pm 2.47$ & $63.65 \pm 2.22$ & $72.28 \pm 1.37$ & $77.34 \pm 1.77$ & $83.27 \pm 1.57$ & $9.58 \pm 0.68$ \\
AQ & $18.12 \pm 3.12$ & $35.42 \pm 2.88$ & $76.72 \pm 2.08$ & $82.91 \pm 3.47$ & $88.61 \pm 2.19$ & $90.57 \pm 0.94$ & $92.19 \pm 2.61$ & $4.11 \pm 0.94$ \\
CH & $8.38 \pm 0.89$ & $12.77 \pm 0.96$ & $32.37 \pm 1.37$ & $48.76 \pm 0.67$ & $54.37 \pm 3.37$ & $65.29 \pm 2.49$ & $68.37 \pm 3.21$ & $15 \pm 1.32$ \\
Ascorbic acid & $20.94 \pm 1.67$ & $41.16 \pm 1.08$ & $78.28 \pm 3.07$ & $87.61 \pm 1.28$ & $91.19 \pm 0.82$ & $94.37 \pm 0.79$ & $96.49 \pm 1.47$ & $2.76 \pm 0.75$ \\
\hline
\end{tabular}

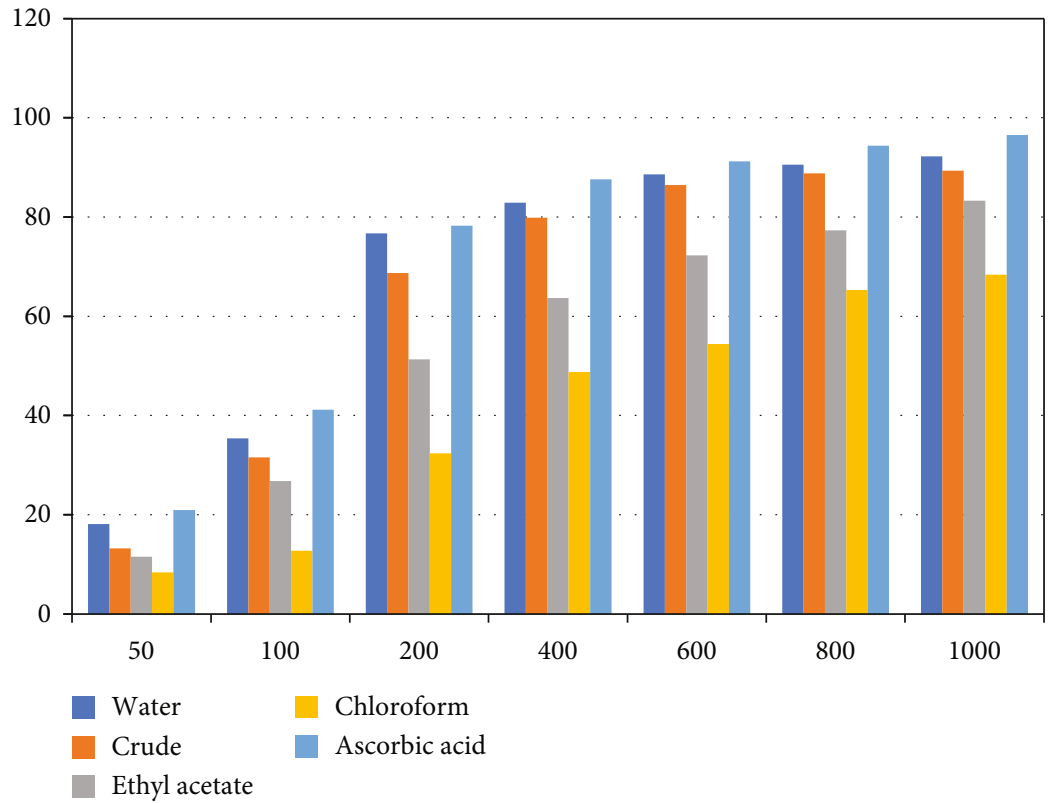

Figure 1: DPPH free radical scavenging activity of crude and solvent fractions of Echinops kebericho.

and significantly higher antipyretic activity than the chloroform fraction $(p<0.01)$. The time-dependent antipyretic effects of the crude extract and the solvent fraction suggested that the effects also have a potential kinetic profile (Table 1).

The antipyretic activity of the crude extract and its different solvent fractions shown from this study is in line with previous reports which stated that plants having analgesic and anti-inflammatory potentials may possibly possess a significant antipyretic activity $[19,23]$.

The presence of the active chemical constituents such as steroids, terpenoids alkaloids, and saponins in the root extract of $E K$ [24] played a significant role in the antipyretic activity of the extract. Steroids and terpenoids have exerted their antipyretic effect through inhibiting the activity of prostaglandin synthetase, the enzyme that stimulates the production and release of PGs, the primary mediator in fever induction, while flavonoids inhibit elevating temperature by suppressing mediators like PGs responsible for fever, through its action against the release of AA or by interfering with the eicosanoid biosynthesis pathways involved in fever production $[16,22]$.

Since the lowering of temperature was almost in a similar manner to that of the reference drug, ASA, the proposed anti- pyretic property of the extract can be assumed to be through the interference of PG synthesis and inhibition of cytokine release which play a major role for the elevation of body temperature $[18,22]$.

\section{Conclusion and Recommendation}

Standing from the results gained from the present study, it can be concluded that the experimental plant extract and its solvent fraction possessed antipyretic and antioxidant activities. The crude extract and aqueous fraction in the doses of 100,200 , and $400 \mathrm{mg} / \mathrm{kg}$ significantly reduce the temperature of pyretic mice as revealed from the observation that the average percentage of antipyretic activity increased with the concentration of the extracts and its solvent fractions ( $400 \mathrm{mg} / \mathrm{kg}$ ) as compared with the negative control groups. It is presumed that the presence of active phytoconstituents including flavonoids may be contributed to the antipyretic activities of both the extract and its solvent fraction through inhibiting the synthesis and release of different pyrogens including PGs. The current findings put scientific evidence about the traditionally claimed uses of E. kebericho for high fever conditions in Ethiopian folk medicines. 
Further constituent isolation, binding studies, and electrophysiological procedures may be useful to fully elucidate the antipyretic and antioxidant effects and specific mechanisms of E. Kebericho.

\author{
Abbreviations \\ AA: Arachidonic acid \\ AF: Aqueous fraction \\ ASA: Acetyl salicylic acid \\ EAF: Ethyl acetate fraction \\ EK: Echinops kebericho Mesfin \\ IC: Effective concentration \\ IFN: Interferon \\ IL: Interleukin \\ PGs: Prostaglandins \\ TNF: Tumor necrosis factor.
}

\section{Data Availability}

All data that are analyzed are available on the hand of the corresponding author.

\section{Ethical Approval}

Ethical clearance was obtained from the Department of Pharmacology, School of Pharmacy, College of Medicine and Health Science, University of Gondar.

\section{Conflicts of Interest}

All authors report no conflicts of interest in this work.

\section{Authors' Contributions}

TY and ZD conceived the idea, drafted the proposal, collected the plant materials, and conducted the actual laboratory work. TY, AE, and YK prepared and critically reviewed the final manuscript for publication. EM, ZD, and MA were involved in the design and implementation stage of the study and revision of the manuscript critically for important intellectual content. All authors read and approved the final version of the manuscript.

\section{Acknowledgments}

We would like to acknowledge Debre Tabor University for helping us financially. We are also most grateful to Gondar University National Herbarium for authenticating the plant species. We would also like to acknowledge Mr. Alemante Tesfa and Mr. Abriham Degu, School of Pharmacy, University of Gondar, Ethiopia, for their contribution during each experimental procedure.

\section{References}

[1] J. E. Sullivan, H. C. Farrar, the Section on Clinical Pharmacology and Therapeutics, and Committee on Drugs, "Fever and antipyretic use in children," Pediatrics, vol. 127, no. 3, pp. 580-587, 2011.
[2] S. Dalal and D. S. Zhukovsky, "Pathophysiology and management of fever," The Journal of Supportive Oncology, vol. 4, no. 1, pp. 9-16, 2006.

[3] D. Ogoina, "Fever, fever patterns and diseases called 'fever' - A review," Journal of Infection and Public Health, vol. 4, no. 3, pp. 108-124, 2011.

[4] Y. Li and J. Tian, "Evaluation of local anesthetic and antipyretic activities of Cinchona alkaloids in some animal models," Tropical Journal of Pharmaceutical Research, vol. 15, no. 8, pp. 1663-1666, 2016.

[5] Y. Tamrat, T. Nedi, S. Assefa, T. Teklehaymanot, and W. Shibeshi, "Anti-inflammatory and analgesic activities of solvent fractions of the leaves of Moringa stenopetala Bak.(Moringaceae) in mice models," BMC Complementary and Alternative Medicine, vol. 17, no. 1, p. 473, 2017.

[6] A. Tadele, K. Asres, D. Melaku, and W. Mekonnen, "In vivo anti-inflammatory and antinociceptive activities of the leaf extracts of Clematis simensis Fresen," Ethiopian Pharmaceutical Journal, vol. 27, pp. 33-41, 2009.

[7] Y. Tariku, A. Hymete, A. Hailu, and J. Rohloff, "In vitro evaluation of antileishmanial activity and toxicity of essential oils of Artemisia absinthium and Echinops kebericho," Chemistry \& Biodiversity, vol. 8, no. 4, pp. 614-623, 2011.

[8] G. Ameya, A. Gure, and E. Dessalegn, "Antimicrobial activity of Echinops kebericho against human pathogenic bacteria and fungi," African Journal of Traditional, Complementary and Alternative Medicines, vol. 13, no. 6, pp. 199-203, 2016.

[9] T. Teklehaymanot, M. Giday, G. Medhin, and Y. Mekonnen, "Knowledge and use of medicinal plants by people around Debre Libanos monastery in Ethiopia," Journal of Ethnopharmacology, vol. 111, no. 2, pp. 271-283, 2007.

[10] G. G. Mengesha, "Ethnobotanical survey of medicinal plants used in treating human and livestock health problems in Mandura Woreda of Benishangul Gumuz, Ethiopia," Advancement in Medicinal Plant Research, vol. 4, no. 1, pp. 11-26, 2016.

[11] B. Abera, "Medicinal plants used in traditional medicine by Oromo people, Ghimbi District, Southwest Ethiopia," Journal of Ethnobiology and Ethnomedicine, vol. 10, no. 1, p. 40, 2014.

[12] Z. Getnet, S. Chandrodyam, and G. Masresha, "Studies on traditional medicinal plants in ambagiorgis area of Wogera District, Amhara Regional State, Ethiopia," International journal of pure and applied bioscience, vol. 4, pp. 38-45, 2016.

[13] E. d'Avigdor, H. Wohlmuth, Z. Asfaw, and T. Awas, "The current status of knowledge of herbal medicine and medicinal plants in Fiche, Ethiopia," Journal of Ethnobiology and ethnomedicine, vol. 10, no. 1, p. 38, 2014.

[14] Council NR, Guide for the Care and Use of Laboratory Animals, National Academies Press, 2010.

[15] Y. Alemu, Z. Mekonnen, A. Zeynudin, M. Yohannes, A. Biruksew, and S. Suleman, "Anti-schistosomal activities of Echinops kebericho Mesfin root and Hagenia abyssinica (Bruce) J.F Gmel flower part crude extracts in Swiss albino mice," Asian Pacific Journal of Tropical Medicine, vol. 11, no. 10 , p. 570, 2018.

[16] S. VZ, K. JK, N. PM, N. MP, O. G, and N. EM, “Antipyretic, antiinflammatory and antinociceptive activities of aqueous bark extract of Acacia nilotica (L.) Delile in albino mice," Pain Management Medication, vol. 2, no. 2, p. 2, 2016.

[17] S. Tesema and E. Makonnen, "In Vivo Analgesic and Antipyretic Activities of N-Butanol and Water Fractions of Ocimum 
Suave Aqueous Leaves Extract in Mice," Ethiopian journal of health sciences, vol. 25, no. 2, pp. 139-146, 2015.

[18] S. Ahlawat, P. Mishra, K. Dalal, and A. Patra, "Antipyretic activity of roots of Argyreia speciosa (burm. F.) Bojer," International Journal of PharmTech Research, vol. 2, no. 4, pp. 2165-2167, 2010.

[19] E. Makonnen, A. Debella, L. Zerihun, D. Abebe, and F. Teka, "Antipyretic properties of the aqueous and ethanol extracts of the leaves of Ocimum suave and Ocimum lamiifolium in mice," Journal of Ethnopharmacology, vol. 88, no. 1, pp. 8591, 2003

[20] V. Gulati, I. H. Harding, and E. A. Palombo, "Enzyme inhibitory and antioxidant activities of traditional medicinal plants: potential application in the management of hyperglycemia," BMC Complementary and Alternative Medicine, vol. 12, no. 1, p. 77, 2012.

[21] W. Brand-Williams, M.-E. Cuvelier, and C. Berset, "Use of a free radical method to evaluate antioxidant activity," $L W T$ Food science and Technology, vol. 28, no. 1, pp. 25-30, 1995.

[22] W. Mbinda, S. Kasili, J. W. Mbiri, P. D. Kisangau, and N. M. Piero, "Anti-Pyretic Properties of Methanolic Bark Extracts of Terminalia Brownii in Wistar Rats (Rattus Novegicus)," 2016.

[23] N. K. Subedi, S. Rahman, and M. A. Akbar, "Analgesic and antipyretic activities of methanol extract and its fraction from the root of Schoenoplectus grossus," Evidence-Based Complementary and Alternative Medicine, vol. 2016, Article ID 3820704, 8 pages, 2016.

[24] T. Yimer, E. M. Birru, M. Adugna, M. Geta, and Y. K. Emiru, "Evaluation of analgesic and anti-inflammatory activities of $80 \%$ methanol root extract of Echinops kebericho M. (Asteraceae)," Journal of Inflammation Research, vol. 13, pp. 647658, 2020. 